\title{
Educação Médica Continuada
}

O suceder de gerações é como a passagem do bastão na conhecida prova de atletismo - um atleta precisa do outro para o sucesso final. Este pensamento é integralmente válido para nós médicos. O que seria dos novos se não recebessem o bastão de mãos experientes e com grande vivência em sua prática médica?. Da mesma forma, o que aconteceria com os mais antigos, se não encontrassem ninguém para entregar o bastão?.

A história da Medicina seria feita de episódios, às vezes, com valor intrínseco, mas sem nenhuma continuidade. Todos nós estaremos enquadrados nestes dois momentos, às vezes ao mesmo tempo.

A FEBRASGO, com suas atividades de educação continuada espalhada por todo o Brasil, tem nesta filosofia um de seus paradigmas. A troca de bastão será sempre uma forma interessante de atualização para os Tocoginecologistas.

A Diretoria 